DOI: $10.7242 / 1998-2097 / 2018.2 .1$

УДК 551.435 .8

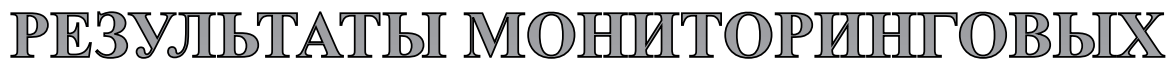

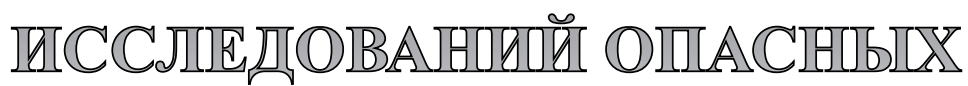

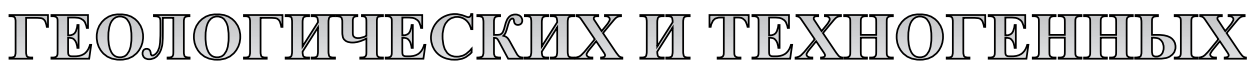

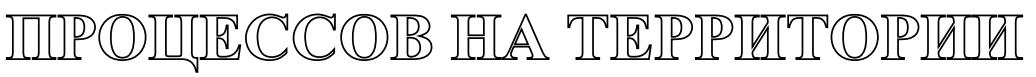 IIUPMICIROIO IKPAYSI B 2017-2018 IT:*
}

\author{
Н.В. Лаврова, Горный институт УрО РАН \\ О.И. Кадебская, Горный институт УрО РАН \\ М.В. Богомаз, Горный институт УрО РАН
}

Представлены результаты обследования опасных геологических процессов (провалов, трещин отседания, просадок) на территории Пермского края с января 2017 г. по июнь 2018 г. Образование поверхностных карстовых форм обусловлено естественными и антропогенными фракторами. Увеличение количества провальных образований в последние годы связано с хозяйственной деятельностью человека. Приведены сведения о ликвидации провалов.

Ключевые слова: мониторинг экзогенных прочессов, провальные явления, карст, опасные геологические прочессы, поверхностные карстовые формы, трещины отседания, ликвидаџия провалов.

Провалы и оседания грунтовых масс занимают особое место среди опасных геологических процессов (ОГП), происходящих в верхней части земной коры, по степени скрытости их протекания, внезапности проявления, катастрофичности последствий и трудности прогнозирования. Строительная и экологическая безопасность, а также экономичность инженерных решений при хозяйственном освоении карстовых районов в первую очередь зависят от конкретных природных условий и степени их изученности в разных регионах. Для предотвращения ряда аварийных и чрезвычайных ситуаций, связанных с развитием карста, и выдачи научно обосно- ванных рекомендаций по строительству на урбанизированных территориях прежде всего нужно четко представлять состояние геологической среды. В этом случае крайне необходим комплекс работ, включающий выполнение режимных наблюдений за провальными явлениями, создание банка наблюденных данных, анализ мероприятий для оценки современной обстановки развития опасных геологических процессов и состояния инженерных объектов, оперативный прогноз развития ОГП.

Специфика природно-техногенных рисков, которые сформулированы в Федеральных законах, а также в государственных и международных стандартах по менеджменту

\footnotetext{
* Работа выполнена при финансовой поддержке Министерства природных ресурсов, лесного хозяйства и экологии Пермского края (государственный контракт № СЭД-30-01-04-33).
} 


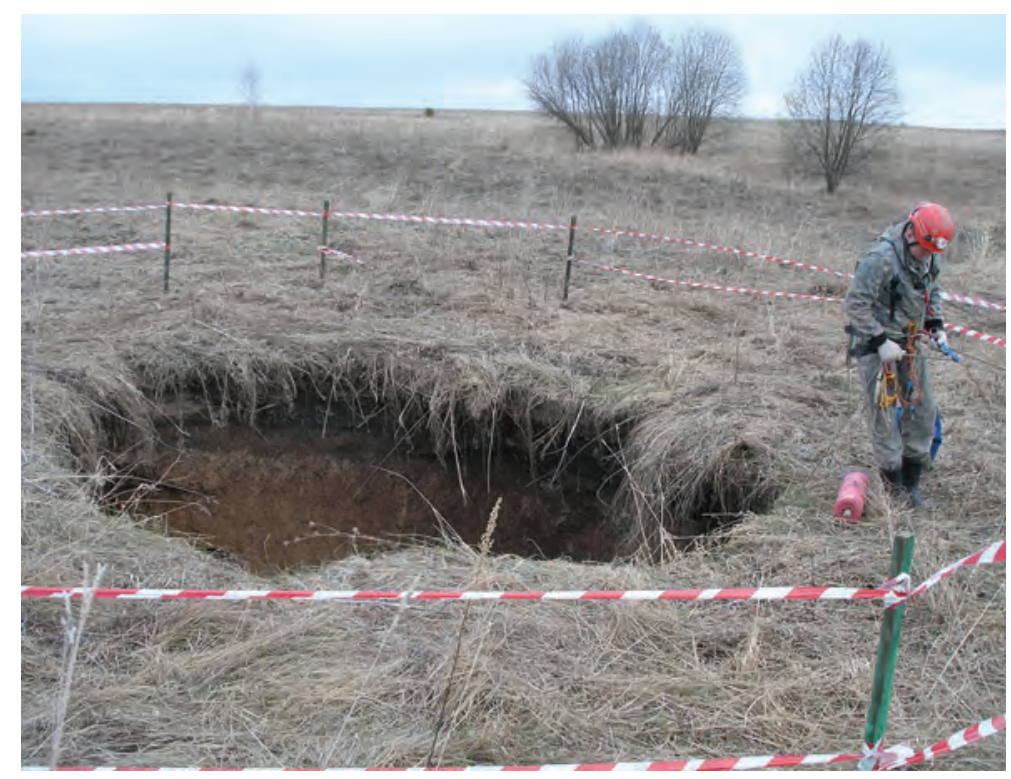

Рис. 1. Провал в с. Родионово, Кунгурский район

риска, приводит к конфликтам во многих сферах, связанных с управлением на территориях, подверженных частым ОГП. В области распространения карстующихся карбонатных и сульфатных отложений на территории Пермского края наиболее часто встречающимися формами опасных поверхностных проявлений карстовых процессов являются провалы. Кунгурская лаборатория-стационар фиксирует случаи образования провалов с 1952 г. При выполнении работ в рамках государственного контракта № СЭД-30-01-04-33 от 22 июня 2016 г. с 1 января 2017 г. по 20 июня 2018 г. на территории Пермского края зарегистрированы и описаны 32 провала, из них 22 произошли на территории г. Кунгура.

Шесть провалов из 32 на территории края связаны непосредственно с развитием карстовых процессов. Среди них провал, расположенный в 300 м на восток от с. Родионово (рис. 1). В геоморфологическом отношении он находится на водораздельной части между логами Каменка, Безымянный, выходящими в долину реки Мечка в 3,2 км от ее устья. Форма провала в плане круглая. Диаметр составляет на поверхности 5,0 м, на глубине 18 м, размеры полости 10,0 х 7,0 м, общая глубина провала 18 м. Форма в разрезе сложная, ниже 12,5 м наблюдается уклон основания на северо-восток. В стенках провала до глубины 4,5 м глина, далее до глубины 12 м - мелкообломочные карстово-обвальные отложения, с 12 до 16 м крупнообломочные карстово-обвальные отложения с глыбами гипса. Легкорастворимые сульфатные породы в районе образовавшегося провала залегают на глубине 10-20 м. Общая их мощность составляет более 25 м. Данный участок относится к территориям с плотностью карстовых воронок от 10 до 50 на км².

Приуроченность большинства крупных провалов к плиоценовым террасам объясняется значительной высотой их цоколя и более высокой плотностью покровных отложений. Большие горизонтальные галереи формируются в сульфатах под покровом пачек карбонатных пород, поэтому наличие таковых над сульфатными породами может указывать на повышенную закарстованность последних и присутствие крупных пустот ${ }^{1}$.

15.05.2018 г. обследован участок полотна автомобильной муниципальной дороги «Мостовая-Насадка» на территории Пермского района, который находится в 1 км

${ }^{1}$ Лукин В.С., Ежов Ю.А. Карст и строительство в районе г. Кунгура. - Пермь: Перм. кн. изд-во, 1975. $118 \mathrm{c}$. 
от паромной переправы Сыра-Насадка. На месте карстового провала, который произошел 17.11.2017 г., уже 4 раза происходили повторные просадки грунта. Провал и последующие просадки обусловлены гидрогеологической активностью зон локализации подземного стока, к которым приурочены подземные формы растворения и гидрогеологической активностью самих форм растворения: расширенных трещин, пор, каверн, полостей, которые находятся в зоне колебания уровня подземных вод и р. Сыра. На этом участке ввиду весьма вероятного повторения провальных и просадочных явлений необходимо организовать постоянное наблюдение за просадками. В будущем желательно предусмотреть возможность переноса участка дороги.

Пятнадцать провалов в г. Кунгуре связаны с карстово-суффозионными процессами, которые произошли вследствие утечек из водонесущих коммуникаций или были спровоцированы зарегулированным стоком поверхностных вод. Наиболее примечательный провал из этой группы образовался в г. Кунгуре, ул. Криулинская, 7, под машиной УАЗ (рис. 3). Поперечник провала составил 3,0 м и глубину 2,0 м. Ранее в районе провала наблюдалась небольшая просадка диаметром 5,0 м и глубиной 0,3 м. К просадке по ложбине между рядами гаражей в течение длительного времени происходил сток дождевых и талых вод. По горизонтальным трещинам в полость в карстующихся породах с поверхности осуществлялся постоянный приток воды, что и послужило причиной образования провала.

Четыре провала образовались при обрушении засыпанных погребов и склепа у здания Тихвинской церкви (г. Кунгур), шесть провалов - в результате просадок грунта над горными выработками шахтных полей на территории пос. Скальный и к юго-западу от пос. Половинка (Чусовской район).

23.08.2017 г. сотрудниками Кунгурской лаборатории-стационара по запросу Кунгурской епархии обследованы просадка грунта и трещины в храме Михаила Архистратига в с. Сажино Березовского района. Трещины могли образоваться при медленных просадках грунта над карстовой пустотой, находящейся на глубине от $30 \div 100$ м. Для выбора конструктивных противокарстовых мероприятий было рекомендовано проведение геофизических работ с целью оконтуривания пустоты и определения ее морфометрических показателей.

Многолетний опыт показал, что трещины и деформации в зданиях и сооружениях, зачастую приписываемые проявлению карстовых процессов, обычно объясняются другими неблагоприятными факторами.

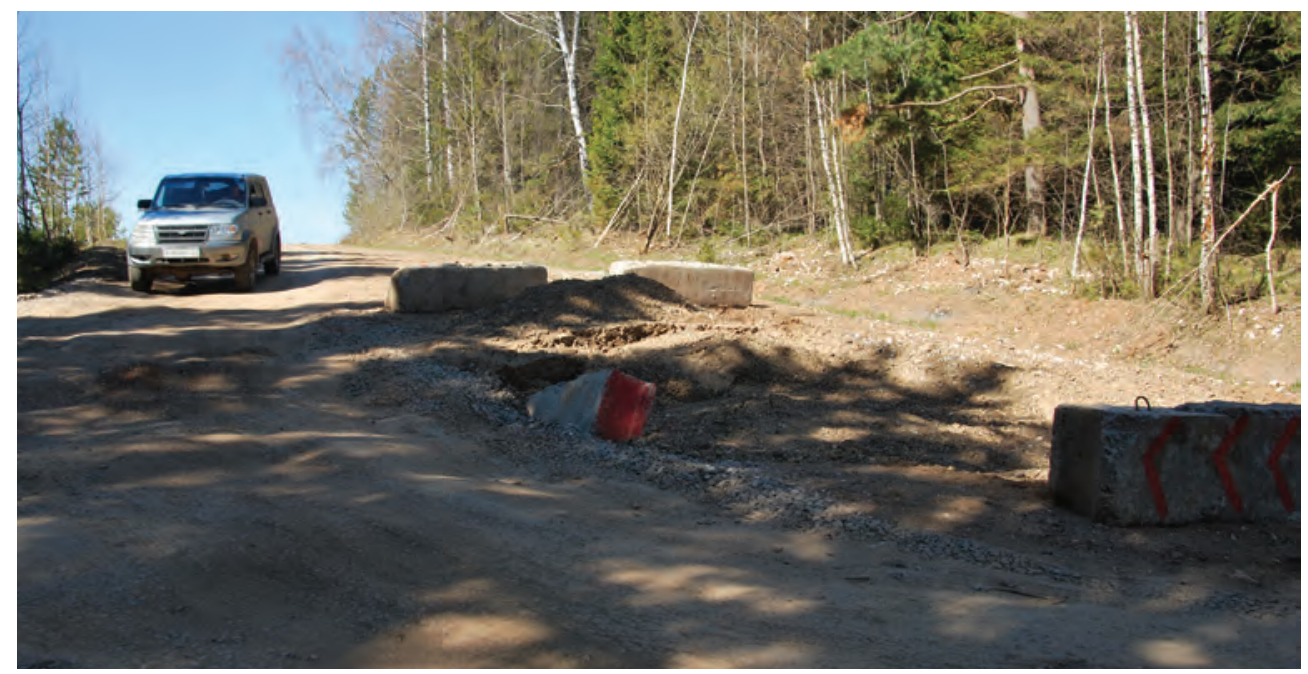

Рис. 2. Просадка на месте засыпанного провала на дороге Мостовая-Насадка (15.05.2018 2.) 
В большинстве случаев они связаны с суффозионным выносом поверхностных отложений, переувлажнением и неравномерным снижением несущей способности грунтов на локализованных участках. В мае 2018 г. обследованы трещины и просадки отмостки у жилого дома по ул. Электродеповская, 9а, а также трещины в стенах общежития по ул. Матросова, 23 в г. Чусовом, Чусовского муниципального района Пермского края в связи с обращением жителей. Обследованные участки просадок и трещин в зданиях в г. Чусовом также были связаны с переувлажнением грунтов вследствие незарегулированного поверхностного стока дождевых и талых вод под фундаменты зданий, а также утечками из трубопроводов.

В настоящий момент сведения обо всех провалообразованиях заносятся в базу данных, которая является основным

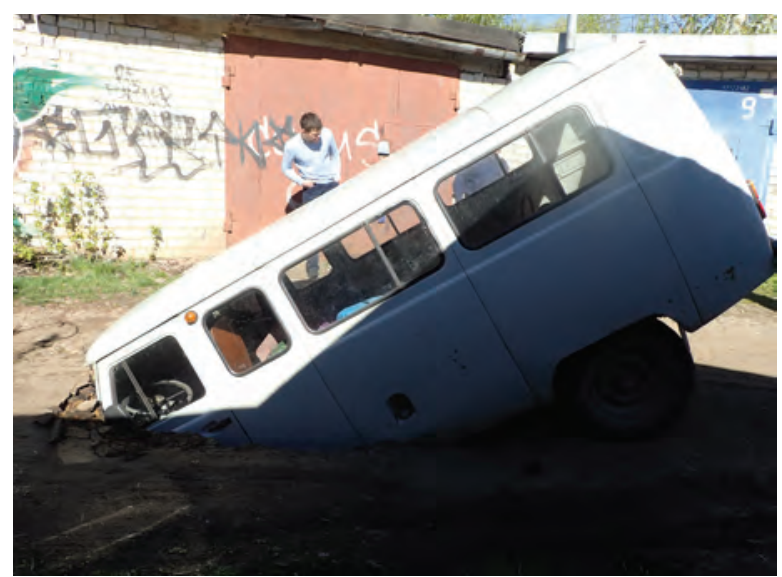

Рис. 3. Провал в г. Кунгуре, ул. Криулинская, 7 исходным материалом для обоснования прогнозных показателей карстоопасности урбанизированных территорий. Представленные результаты исследований могут быть полезны специалистам при разработке проектно-планировочной документации на территории Пермского края.

\title{
THE RESULTS OF THE DANGEROUS GEOLOGICAL AND TECHNOGENIC PROCESSES MONITORINS OF THE TERRITORY OF PERM REGION IN 2017-2018
}

\author{
N.V. Lavrova, O.I. Kadebskaya, M.V. Bogomaz
}

Mining Institute UB RAS

The results of the examination of dangerous geological processes on the territory of the Perm region from January 2017 to June 2018 are considered: failures, cracking, disappearing lakes. The formation of surface karst forms is condutioned by natural and anthropogenic factors. There have been increasing number of karst failures recently as the result of human activities. Information is given on the elimination of failures.

Keywords: monitoring of exogenous processes, failure phenomena, karst, hazardous geological processes, crack otselenie, liquidation of failures of surface karst forms.

\section{Сведения об авторах}

Лаврова Наталья Владимировна, кандидат геолого-минералогических наук, научный сотрудник Кунгурской лаборатории-стационара, Горный институт УрО РАН - филиал Пермского федерального исследовательского центра УрО РАН (ГИ УрО РАН), 614007, г. Пермь, ул. Сибирская, 78А; e-mail: nlavrova08@mail.ru

Кадебская Ольга Ивановна, доктор географических наук, заведующая Кунгурской лабораторией-стационаром, ГИ УрО РАН: e-mail: icecave@bk.ru

Богомаз Максим Викторович, инженер Кунгурской лаборатории-стационара, ГИ УрО РАН; e-mail: bogomaz@mail.ru 